\title{
The Earth as Pinprick: Some Early Western Challenges to Anthropocentrism
}

\author{
Bryan L. Moore \\ Arkansas State University, USA \\ bmoore@astate.edu
}

\begin{abstract}
It is common to assume that the ancient Greeks and Romans were essentially anthropocentric in point of view. While this is partly true (as it is today), the ancients established important precedents that challenge and overturn this view, anticipating modern science and even Darwin and beyond. This article analyzes texts from the Presocratics to late antiquity to show how the questioning of anthropocentrism developed over roughly 800 years. This matters because overcoming our present ecological crises demands that we reassess our place on the earth and draw down our impact on the planet. The ancients show that the questioning of anthropocentrism it nothing new; their work is part of the bridge required to help us move more responsibly into the later parts of the twenty-first century and beyond.
\end{abstract}

Keywords: Ancient Greek and Roman, science, ethics.

\section{Resumen}

Es común asumir que los griegos y romanos antiguos tenían un punto de vista esencialmente antropocéntrico. Aunque esto es cierto en parte (como hoy en día), los antiguos establecieron precedentes importantes que desafían y dan la vuelta a esta perspectiva, anticipándose a la ciencia moderna e incluso a Darwin y más allá. Este artículo analiza textos desde los Presocráticos hasta la antigüedad tardía para mostrar cómo se cuestionó el antropocentrismo durante aproximadamente 800 años. Esto es importante porque para vencer las crisis ecológicas actuales es necesario que re-evaluemos nuestro lugar en la tierra y que reduzcamos nuestro impacto en el planeta. Los antiguos demuestran que cuestionarse el antropocentrismo no es nada nuevo; su trabajo es parte del puente necesario para ayudarnos a trasladarnos más responsablemente hacia el último periodo del siglo XXI y más allá.

Palabras clave: antigua Grecia y Roma, ciencia, ética.

It is common to conclude that the writings in physics, ethics, and literature of the ancient Greeks and Romans, refocused and dogmatized by later Christians, established the anthropocentric mindset that justifies and dictates such practices today as the massive depletion of species, the burning of fossil fuels, and mountaintop removal coal mining. The ancients did tend toward anthropocentrism, just as consumerist-industrialist societies largely do today, ${ }^{1}$ but there are also some

1 Recent public polls on climate change indicate a strongly anthropocentric mindset. Most Americans, for example, believe in global warming but do not believe it is anthropogenic; most Americans do not believe that scientists agree that climate change is caused chiefly by humans (2014). See a detailed study at https://environment.yale.edu/poe/v2014/. Europeans are generally 
important precedents among the ancients in interrogating and rejecting anthropocentrism. In fact, many ancient and medieval writers were open-eyed and, given their limited means for measuring and observing the universe, wellinformed. Many of them did not believe that the earth is the most important part of the universe or that it is particularly unique. Some perceived the earth as tiny, almost irrelevant in the cosmos, and-outside my present scope--many ancients, including Theocritus, Virgil, Horace, and Martial, ${ }^{2}$ wrote about peaceful, placid, and noiseless places of environmental simplicity as contributing to the healthiest development of human life. Even the implications for humans in the astronomical writings of Claudius Ptolemy, whose geocentric system would be standard until Copernicus and Galileo, are still frequently misunderstood; "Ptolemaic" does not imply anthropocentric (Danielson 68). ${ }^{3}$

Many distinguished writers have discussed the worldviews of ancients, including Clarence J. Glacken, David C. Lindberg, Margaret Osler, and Max Oelschlaeger; my much more modest aim in this article is a thumbnail view of a handful of chief figures to show that the anthropocentric mindset-and more importantly for my purposes - its interrogation, has been in circulation for a very long time, at least since the fifth century BCE. ${ }^{4}$ While the vast majority of ancient works are essentially anthropocentric, many of the ideas of the ancients crop up over and over into the present day, including the notion that the earth-and the humans that inhabit it--is a relatively tiny part of the universe, a "pinprick," as Seneca and other ancients described our cosmic position.

Why does this matter to us in the twenty-first century? Beyond sheer historical-literary-cultural interests, if we are going to overcome our global ecological crises-climate change, habitat destruction, species elimination, and so on--we must reassess our place on the earth and draw down our impact on it. Paul J. Crutzen sought in a well-known Nature article to establish our "humandominated, geological epoch, supplementing the Holocene," as the "Anthropocene." 5 Crutzen concludes his article by stating that it is the task of engineers and scientists "to guide society towards environmentally sustainable management during the era of the Anthropocene. This will require appropriate human behaviour at all scales" (23). Philosophically and spiritually, this demands that we revoke a "hard" or extreme anthropocentrism. Writes the British philosopher A.C. Grayling, to have an anthropocentric view is

more aware of climate change; a significant part of the population (20\%) believe climate change is the most important current issue; see http://ec.europa.eu/public_opinion/archives /ebs/ebs_409_en.pdf

2 See Theocritus; Virgil; Horace, e.g., Odes 1.3 and 2.15; and Martial, e.g., Epigrams 3. 26 and 31, $4.66,5.13$, and 12.50 .

${ }^{3}$ Michael J. Crowe notes the complexity of Ptolemy in Amalgest and other works: "Ptolemy had not one, but rather a number of systems - one for each of the main bodies of our system" (43).

${ }^{4}$ See Glacken; Oelschlaeger; Lindberg; and Osler.

5 Although Crutzen's article popularized the term "Anthropocene," it was coined by biologist Eugene F. Stoermer in the 1980s. 
To see everything as having humankind at the centre, or as the measure, or as the chief point of interest; to conceive of the gods as human beings writ large ... to think that nothing has greater value than human beings, and that everything else can legitimately be bent to the service, use or interest of humanity, is to place humankind at the pinnacle of value in the world, and to privilege human existence over other kinds. (17)

Grayling contrasts anthropocentrism with biocentrism, "the view that all life is valuable, not just human life" (17). Although few of the ancients developed the idea of biocentrism in much depth, the seeds of the idea do lie in their work and it is obviously a necessary intellectual step toward objective, nonanthropocentric science and ethics. ${ }^{6}$ This article seeks to show that the questioning or outright rejection of anthropocentrism is not a new idea or as extreme a position as some may imagine. Many of our greatest writers, from antiquity to the near present, have already prepared the way for us. This nonanthropocenric heritage is part of the bridge required to help us move more responsibly into the later parts of the twenty-first century and beyond.

Ancient Greek and Roman thinkers, beginning with the Presocratics, pioneered the seeking of rational explanations for the world not out of a Baconian desire to subdue or control nature, but to explore the place of humans in the greater world. The natural philosophy that began in sixth-century Miletus with Anaximader and Anaximenes represents the first attempt "to understand the phenomena of nature in purely physical or mechanical terms" (Kahn 2). The ancient Greek and Roman study of nature (phusis) made no claims about rigor; it did not, like modern science, exist for its own sake, but for what Pierre Hadot calls "a moral finality" (208). The detached distance experienced in the writings of some of the ancients comprises a view of ourselves from above everyday life to show us the things that matter most-not luxury, power, fame, and the like, but philosophy. Hadot states that such a point of view is a sort of "exercise of death. One might say that this exercise has been, since Plato, the very essence of philosophy" (207). The tendency to strip ourselves of "the human" is constant through many ancient schools of philosophy (211).

Of course, the ancient Greeks and Romans did not use the words anthropocentrism or ecology in their writings. ${ }^{7}$ Yet many ancient philosophers anticipate the language of modern ecology and cast doubt on the centrality of humans in the world-sometimes within the same contexts. Plato and others up until the birth of modern science appropriated the careful observations of the

\footnotetext{
${ }^{6}$ On the relationship between stoic science and ethics, Lawrence C. Becker writes, "When we say ethics is subordinate to science we mean, among other things, that changes in our empirical knowledge are likely to generate changes in ethics. When the best science postulate a cosmic telos, as it sometimes did in antiquity, so does stoic ethics. When the best science rejects the view that the universe operates teleologically, in terms of something like human purposes, and suspends judgment about whether cosmic processes have a de facto end, convergence point, or destination, so does stoic ethics" (11). For a short discussion of biocentrism and ecocentrism, see Curry.

7 According to Merriam-Webster's New Collegiate Dictionary, both words emerged at around the same time, respectively, 1863 and 1873.
} 
ancient Babylonians, who understood the movements of heavenly bodies as the purposeful activities of the gods. The work of the Greeks, from Thales to Plato's Timaeus, establishes not only Western philosophy but science and the initial conception of nature itself. The cosmic scheme of Democritus and the atomists, writes Charles Kahn, "most fully anticipate[d] the world view of modern science" $(1,2)$ and is an important precedent for Lucretius and his De rerum natura (On the Nature of Things), which was even more central in the birth of modern science.

Among other Presocratics, Empedocles (c. 495-c. 435 BCE), called a "natural scientist" by later ancient writers, evokes protoecological unity in his Physics (extant only in fragments). Change is continuous but, anticipating the Stoics, it is also orderly, personified as Love and Strife; anticipating the Epicureans (he was a substantial influence on Lucretius), he suggests that change in nature is by chance (Early Greek 136). Plutarch quotes Empedocles' statement that "there are effluences from all things that have come into being"; "not only animals and plants and earth and sea, but stones too, and bronze and iron, continuously give off numerous streams" (Early Greek 139). Irrational animals--his fragment cites hedgehogs--are better endowed than humans (Early Greek 150). It is unethical to kill living things, he writes, since there is "a law for all" (see Aristotle, On Rhetoric 1373b.2).

The Stoics would ridicule Empedocles, but he, again, anticipates the Stoics by writing of plants: "There is a single spirit which pervade the whole world like a soul and which unites us with them" (Early Greek 158). Even plants feel pain (159). Empedocles suggests a poetic, affirmative view of relationship between us and animals (161). In contrast to Aristotle's later understanding of final causes, laid out in Book II of Physics (especially 8.198b-199a), Empedocles suggested a natural selection in which only the most successful organisms would succeed. Though he does not provide evidence for such a theory, he does anticipate Darwin's On the Origin of Species by about two millennia. ${ }^{8}$ Stoic physics, as it turns out, would be central in the questioning of anthropocentrism, even if Epicureanism more centrally espouses the rejection of this view.

Plato and Aristotle are often cited as the source of many misconceptions about the nature of the universe and the place of humans in it. Their views would largely persist until the observations of Galileo and the mechanical philosophies of Gassendi and Descartes in the seventeenth century. Plato and Aristotle held a teleological view of the cosmos, as did Anaxagoras before them, though their teleological bases are very different. Plato (and Socrates) turned away from the natural philosophy of many of the earliest Greek philosophers, though works such as Timaeus and Laws are attempts to explain the universe, mythically but also rationally-through mythos and logos. In Phaedo, we learn that "natural science"

\footnotetext{
8 In late editions of On the Origin of Species, Darwin cites both Empedocles and Aristotle on evolution in Physics, though he doesn't acknowledge that Aristotle's views are in contrast to Empedocles'.
} 
consisted (says Socrates) of a search for "the causes of everything; why it comes to be, why it perishes and why it exists" (96a). Related to his sense of political and ethical order, Plato rejects the materialism of the Presocratics in the thoroughly teleological scheme of Timaeus, which explains the universe as the ordered result of a single beneficent demiurge or "Craftsman" (29a-b). In contrast to the chancegoverned materialism of the atomists, the demiurge imposed order on the cosmos, and the heavenly bodies are alive.

Aristotle rejects the teleological basis of his great teacher Plato; for Aristotle, order has always existed. As he writes regarding "the four types of cause" in Physics, every natural process acts toward an "end or that for the sake of which a thing is done" (2.3). For Aristotle, the stationary earth is at the center of the finite universe, yet it is of no great size when compared to the fixed stars (On the Heavens 2.14). Following Plato, he writes that the divinity of the earth decreases from its circumference to its center-an idea one may observe in many later works, including Dante's Inferno, which places Satan at the very center of the earth's core. Plato's conception of the self-moving stars is impossible, though Aristotle has little to say about the "unmoved mover" in his treatise On the Heavens. ${ }^{9}$

The Stoics (beginning with Zeno of Citium in the fourth and third centuries BCE) re-enforced the anthropocentrism espoused by Plato and Aristotle: humans are in an elevated position. Of course, Christian thinkers would develop this idea in various ways, though they would largely abandon Stoicism for Platonism by late antiquity. Diogenes Laërtius, quoting the Stoic Posidonius (135-51 BCE), writes that the substance of the universe is "a complex of heaven and earth and the nature in them or a complex of god and humans and the things that come to be for their sake" (Stoics Reader 52). Yet some Stoics diminish the importance of human affairs in their works and even veer closely towards a rejection of anthropocentrism. Animals are below humans for most Stoics, yet central to their philosophy is the idea of the unity of all things which is derived from the Presocratics. Not all users of the topos proceed in the same way, other than in diminishing man for whatever reason. Humans are small if one considers the great size of the world, though early Stoics tended to stress the notion that the earth is the absolute center of the cosmos. Stoic physics was an attempt to elevate the legacy of myth and legend "into science and philosophy, and to combine it with the cosmology of Heraclitus, seeing the world as flux and fire, conflagration and return" (Gillispie 182). The movement away from myth to science in the Hellenistic age goes hand in hand with a move away from teleological explanations of the universe and from anthropocentrism.

Cicero was a self-styled Academic, following Plato, but his understanding of the universe is clearly indebted to Stoic thought, especially by way of his friendship

\footnotetext{
${ }^{9}$ In The Inferno, Dante places Aristotle in his Limbo, along with Socrates and Plato, Democritus ("who strove to show / That the world is chance" [4.120-21]), Diogenes, Seneca, Averroes, etc. Satan is frozen in Lake Cocytus at the center of the earth in Canto 34.
} 
with Posidonius. In Book I of The Laws, Cicero lays out principles of natural law, including the ideas that the universe is ordered by rational providence and that man, a single species, stands between God and the animals; he is possessed of both animal needs and a godlike reason (1.1-57). As Niall Rudd writes, until recently "most people agreed with Cicero and the Stoics in assuming that man's dominion over the animals ... was in accordance with natural law," oblivious to the idea that humans are capable of squandering resources, pollution, and anthropogenic extinction to such a high degree (The Republic and The Laws xxxi).

Cicero was a Roman transmitter of Hellenistic thought rather than an original thinker. His The Nature of the Gods is chiefly a debate between Stoic, Epicurean, and Academic philosophies. In the dialogue, he appears to side largely with a Stoicism that represents a strongly anthropocentric viewpoint. The dialogue wastes no time jumping into the main questions at hand: Do gods exist? If not, does the absence of gods create chaos? If there are gods, what is their nature? (In antiquity natural philosophy and theology were inextricably tied.) Is the worship of the gods a "mere façade"? Cicero states that many esteemed philosophers hold that the universe is ordered, that all that occurs (weather, seasons, and the like) is created and "bestowed by the gods on the human race" (1.4).

Set forth first in the dialogue is the Epicurean case, presented by Gaius Velleius, who speaks, Cicero notes, "with the breezy confidence customary of Epicureans" (1.18). Stoics, Velleius charges, "prefer dreaming to reasoning" (1.19), and he ridicules the Stoic (and Platonic) notion that the whole cosmos is sentient and that the gods created the world for humans. He asks whether the gods made the world for all humans or only for the wise or for fools (1.23). Anticipating Hume's Dialogues Concerning Natural Religion, ${ }^{10}$ he asks, rhetorically, why, if god made the world for humans, so much of the earth is uninhabitable for humans (1.24). He mocks the notion of fate, or Heimarmene, which holds that "every chance event is the outcome of an eternal verity and a chain of causation. How much respect can be accorded to this school of philosophy, which like a pack of ignorant old women regards all that happens as the course of fate?" By contrast, Epicurus (the founder of Epicureanism) brought freedom by teaching us to not fear superstition or the wrath of the gods (1.56) - an idea that would be developed by Cicero's younger contemporary Lucretius.

Responding directly to Velleius, Cicero has (Quintus Lucilius) Balbus deliver a rundown of the Stoic case, which is, of course, markedly anthropocentric. He quotes the great Stoic Chrysippus in making a case for the existence of the gods, and in the process he shows the elevated state of man: if there are no gods, then nothing is better than man because he has reason (2.16). All things in the universe, Balbus continues, "have been created and prepared for us humans to enjoy," and "all that exists in the entire universe must be regarded as the possession of gods

\footnotetext{
${ }^{10}$ Hume undermines the argument by design (in part) by arguing that the earth contains too many flaws to have been created by an omniscient, beneficent deity.
} 
and men," including animals (2.155-56). Representing Cicero's own Academic skepticism, in Book 3, (Gaius) Cotta takes the edge off of Balbus' strict anthropocentrism by elucidating Chrysippus: if gods don't exist, nothing is naturally better than men, yet, said Chrysippus, to state that nothing is better than men is "supreme arrogance" (3.26). He mocks the Stoic claim that the gods have bestowed on man alone the faculty of reason (3.66). The gods, he continues, do not think of or care about human cities, much less humans themselves, which providence holds "in contempt" (3.93).

Weighing up the degrees of final causes and anthropocentrism, Cicero appears to back away from what one might call hard-line anthropocentrism. Like many ancients, including Seneca, who I discuss below, Cicero is genuinely interested in philosophy for its own sake and not as a rote set of laws that one should dogmatically follow without question. Other Cicero works underscore the impulse to move away from hard anthropocentrism, including The Dream of Scipio, which comprises the sixth and final book of On the Republic. The importance to the history of ideas of The Dream of Scipio is difficult to overestimate; it would be a model for other writers, including Macrobius, whose Commentary on the Dream of Scipio was studied closely throughout the Middle Ages. The piece is derived from Plato's The Myth of Er, which concludes his own Republic, and it is narrated by the second century (BCE) general Scipio Aemilianus, destroyer of Carthage, who recounts his service as a military tribune in Africa.

Set in a Platonic-Aristotelian geocentric universe of fixed stars and a motionless earth, Scipio falls into a deep sleep and is visited by the shade of his adopted grandfather, the Roman general Scipio Africanus, hero of the Second Punic War, who speaks of duty to the state and the younger Scipio's future. In the dream Scipio is positioned in the stars, where he notes how small the earth is; the Roman Empire is only a tiny point on a tiny surface. The earth, says Africanus, is "in the middle of this celestial space" (6.15), and Scipio sees the "whole universe" which includes many stars that greatly exceed the earth in size. The earth, he says, "seemed so small that I felt ashamed of our empire, whose extent was no more than a dot on its surface" (6.16). Given this context of a motionless earth positioned in the lowest sphere, humans are incapable of hearing the Pythagorean music of spheres (6.18-19). The elder Scipio sees that his grandson is gazing on the tiny earth and says,

I notice you are still gazing at the home and habitations of men. If it seems small to
you (as indeed it is) make sure to keep your mind on these higher regions and to
think little of the human scene down there. For what fame can you achieve, what
glory worth pursuing, that consists merely of people's talk? Look. The earth is
inhabited in just a few confined areas. In between those inhabited places, which
resemble blots, there are huge expanses of empty territory. (6.20)

He goes on to show how large areas of the earth are uninhabitable or occupied by non-Romans. "In the remaining areas of the east or west," he says, "who will ever hear your name?" (6.22). The fact that his speech avows a position of humility may 
at first seem anti-Roman, since the Romans, Cicero included, so revered their ancestors and statesmen. Posterity forgets us all eventually. On the brink of overthrowing Carthage, Scipio receives a giant dose of humble pie from his honored kin. Of course the disavowal of earthly fame is purely Stoical by nature, and Scipio vows to live in the future with "a much keener awareness" (6.26).

Yet the elder Scipio also echoes the critique of Stoicism by the Epicurean Velleius in The Nature of the Gods: if the gods created the earth for human use, why is so little of it hospitable for human life? Far less a statement opposing anthropocentrism than an attempt to mortify human ambition, the idea that the earth is but a pinprick in the rest of the universe would be explored and expanded on by later writers. Of course, Copernicus, then Galileo, Newton, Herschel, Hubble, NASA space probes, and contemporary astrophysics would in time demonstrate the literal truth of this idea. Outside of Cicero, according to Polybius, after issuing the order to raze Carthage, Scipio Aemilianus said, "A glorious moment, Polybius; but I have a dread foreboding that some day the same doom will be pronounced on my own country" (38.5.21).

Lucretius is doubtless the key Epicurean figure, and he is also central in the rational questioning of anthropocentrism. ${ }^{11}$ Lucretius writes in De rerum natura that the gods have no concern for humanity and the world, which is the result of the chance collision of atoms. Implicit in his view is a strong antianthropocentrism: "not for us and not by gods / Was this world made. There's too much wrong with it!" (2.181-82). Although Epicureans have an implicitly cyclical view of the world, Lucretius tends to ignore this. Near the end of Book 2, he envisions an exhausted earth, and like the writing of Seneca (see below), the book may be called ecocatastrophic, as in the famous lines in which he writes of a "shipwreck with spectator" - the enjoyment of catastrophe from a distance (De rerum natura 2.1-2). In his celebrated book The Swerve: How the World Became Modern, Stephen Greenblatt shows the influence of Lucretius in the making of a modern, rational view of the cosmos. The reintroduction of Lucretius was central in the Renaissance and the birth of modern science. Writes Greenblatt regarding De rerum (4.1105+), "Human insignificance-the fact that it is not all about us and our fate-is, Lucretius insisted, the good news" (199).

In Natural Questions, Seneca (55 BCE-41 CE) is heavily Stoic in attempting to understand nature and its relation to ourselves. Harry M. Hine writes that it is surprising that Seneca wrote such a long work about physics, but he had, like Lucretius, an ethical aim: to lift the mind from narrow human concerns and survey the world as a whole-"the contemplation of the physical world complements moral action by shunning the full context of human action" (Seneca xvii). The focus throughout is on nature and natural events, but the human context is always near as he espouses the Stoic belief in the essential, inherent dignity and worth of all

11 Virgil was also an Epicurean, and he is certainly the great Roman writer, but his poetry is less directly concerned than Lucretius' with Epicureanism per se. 
humans. Yet, veering toward materialism, the nonhuman is also possessed of inherent worth through the idea that even inanimate things have vital spirit, or pneuma; the earth itself breathes (6.16.1). We learn about ourselves by studying the great variety of nature; it is the means by which the mind can understand itself (7.25.1). We can learn the importance of things and interrelationships by looking outside ourselves to nature. So, he writes, shifting subjects, "let us inquire about terrestrial waters" (3.1.1). The Stoic notion that the earth is a living creature with a soul that can experience stress (6.14.2) holds some obvious comparisons with the twentieth-century Gaia theory of British engineer James Lovelock. ${ }^{12}$

As a result of his belief in the unity of all things, at times Seneca displays a protoecological and environmental awareness rather unusual for an ancient. He warns against the misuse of natural resources, and the pollution of the heavens is contrary to Stoic philosophy, which posits a tense relationship between the cosmos and its parts-the pneuma results in cosmic sympathy, something close to what we would term "ecology" today. He writes, "we cannot complain about god our maker if we have corrupted his good gifts" (5.18.13). The book holds many warnings against living for mere luxury and greediness; for example, mines are used by the greedy (15.1). (One may temper such thoughts with the knowledge that Seneca, Nero's counselor, was extraordinarily rich. He has been attacked as a hypocrite over the centuries, but many have defended him.)

Seneca is, like Cicero, also open to other philosophies, including Epicureanism. Natural Questions rejects conventional Stoicism in its backing away from teleological explanations and anthropocentric reasoning. Seneca does not mention Lucretius or Epicureanism, but the book shares characteristics with Lucretius in presenting a rational explanation of events often attributed to malevolent or arbitrary gods - the attempt to replace fear with knowledge-and learn about ourselves along the way. The mind gains strength from the study and contemplation of nature and allows us to "stand above the abyss unflinching." Death is "not a great thing," being only a law of nature (6.32.5).

Again recalling Cicero in Scipio, Seneca, though centrally involved in Roman politics, appears to attack the imperialism of Rome. Earthly empires are insignificant when compared to the immensity of the cosmos. But he is less concerned with political power than with understanding the world philosophically, to measure "the world on its own scale," and to show "that the earth occupies just a pinprick" (4.11.4). For Seneca, almost everything in nature supports the idea that "god did not make everything for human beings." Observing comets, for example, should show "How small a part of this vast creation is entrusted to us!" (7.30.3). He critiques the Etruscan teleological ascription of everything to a god; they say that clouds collide so that they will produce lightning. But Seneca is more given to the

${ }^{12}$ Lovelock's Gaia theory, named after the ancient Greek representation of the Earth, argues that all living entities, from simple (a virus) to complex (a whale), comprise a single living entity. See Lovelock. 
"coincidence" of natural events: the fates are not involved in the minutiae of nature (2.35.2). Near the end of the text, he wryly combines a Stoic view of death with the randomness of natural events: "But if you think that the turmoil of the heavens and the strife of the storms is being arranged for your sake, if the clouds are gathering and colliding and crashing on your account, if such powerful fires are being unleashed for your destruction, then count it a comfort that your death is so important" (2.59.12). He compares human operations with the activities of ants. Were they possessed of human intelligence, they would divide the world into provinces, yet this, again, only shows how, on the larger scale with which Natural Questions is concerned, kingdoms are only a "pinprick" (1.1.11).

Seneca's great book is certainly one of the earliest works of ecocatastrophe written from a rational perspective, and this major theme seems to undermine Stoic anthropocentrism. Echoing Velleius in Cicero's The Nature of the Gods and anticipating (again) Hume, he asks why, if the gods have created the earth for our benefit, life is so marked by overwhelming events. Humans are "short-lived, frail creatures" who are subject to earthquakes (6.1.14). Sea torrents grow and wash the wreckage of nations into itself, containing human civilizations; afterwards, "remnants of the human race" cling to the heights (3.27.12). Yet (echoing Lucretius) earthquakes and the like don't happen because of a god: "these things," he writes, "have their own causes" (6.3.1). Natural catastrophes are very much in step with the unity of nature (3.27.1-3), a unity that extends to our own bodies, including human bleeding as a natural counterpart to the flow of earthly waters (3.15) and even farting and the emission of air from the earth (5.4.1-2).

The Renaissance translations of Pliny the Elder's writings led to the study of natural history (Osler Reconfiguring 132-33). Pliny's studies of a vast array of animals, geology, and other sciences (many of them premodern) were accompanied by his (more modern) observation of the human place in the greater world. In his massive Natural History, he casts doubt on the idea that Nature created everything for man. For Pliny, "It is ridiculous to think that a supreme being-whatever it is-cares about human affairs" (2.20). Like Roman writers before him, he attacks through ridicule the notion that humanity is at the center of the universe because we are so frail: "Pride of place will rightly be given to one for whose benefit Nature appears to have created everything else. . . man is the weakest among all living creatures" (7.4). Monkeys, he notes, are much like humans (11.246), and "only he who is always mindful of the frailty of man will weigh life in a fair balance" (7.44).

Lucian (c. CE 115-after 180) was probably the next significant thinker on anthropocentrism. Born in Samosota (modern Syria), he spoke Aramaic or Syrian but wrote in Attic Greek. A number of his philosophical dialogues attack human pettiness and the arrogance of the wealthy as well as what he saw as the foolishness of philosophers and, often, human nature itself, though he holds room for praise of those who live honestly, humanely. He is thus an important precedent 
for Voltaire, Swift, and Twain. Lucian was a clear model for Johannes Kepler in his Somnium, which defends Copernicus' theories on the movement of the earth. ${ }^{13}$ While it would be overstretching the truth to state that Lucian's dialogues explicitly reject anthropocentrism, they often veer in this direction. His Charon or the Observers was influenced by the Greek Cynics during the Second Sophistic, in which Romans looked back to Attic Greek writing of the Golden Age for inspiration. Cynics (like Socrates) are ascetics; virtue and self-sufficiency are the goals of life. ${ }^{14}$ Cynic Menippus, the third-century BCE Greek satirist, was a enormous influence on Lucian. C.D.N. Costa, in his preface to Charon, writes that the vanity of human aspiration and the mutability of fate are themes derived largely from Cynic ideas (13). Hermes states that if people were more aware of how fleeting human life isas temporary as foam bubbles in a spring-they would live more reasonably and feel less grief over death. Cities die, says Hermes, as do even rivers (23). Elsewhere, Lucian, as is the wont of many satirists, takes a darker view of humanity. In Dialogues of the Dead a series of shades, including Diogenes, Menippus, Pythagoras, Socrates, and Alexander, along with gods associated with the underworld, Charon, Pluto, Cerberus, and Hermes, underscore human vanity.

His Icaroneipuss or High above the Clouds is a satirical dialogue, the title of which combines Menipuss and Icarus. The former, the main speaker in the dialogue, flies on wings to the moon, then to Olympus, where he meets the gods, including Zeus. Largely a sideswipe at philosophers both well-known and obscure, Menippus pays considerable money for their learning but becomes confused with their talk of "first principles, final causes, atoms" (5). Determined to find wisdom, he flies to the heavens by attaching to himself the wing of an eagle and another from a vulture. On the moon, he notes that the earth is-echoing Cicero's Scipiotiny, smaller that the moon. He is visited by Empedocles, who, burnt from the fire of Etna (into whose mouth he is stated in some sources to have cast himself), advises Menipuss to flap only the wing of the eagle to acquire the great bird's vision. In this way Menipuss is able to see the minutiae of the earth and even individual humans. Greece, he observes, is very tiny, and the holdings of the greatest of landowners is merely the size of one of Epicurus' atoms. Visiting heaven, he hears the prayers delivered to Zeus, but they are comically crude, mean, and petty. Zeus pronounces philosophy useless and bids Hermes to send Menipuss unceremoniously back to the earth.

Writers of the early Christian era, following Paul, generally stress the doctrine that since a Christian's true home is not the earth but the kingdom of heaven, "Our spiritual and worldly natures remain separate, and residence on earth is, in the end, inconsequential to the meaning of human life" (Peterson 34). Even suggesting that someone like Augustine is antianthropocentric demands

\footnotetext{
${ }^{13}$ Another important source for Kepler is Plutarch's The Face on the Moon, which the astronomer read in Greek. See John Lear's Introduction to Kepler's Dream (84).

14 The word "cynic" from Greek word for dog: Diogenes the Cynic was, by tradition, "as shameless as a dog." See The Cynic Philosophers: From Diogenes to Julian (xi-xii).
} 
serious qualification; within the spiritual context of contemptus mundi (contempt for the material world as suggested in e.g., I John 2:15), he downplays human significance in its illusory sense of earthly permanence in Book XI of The Confessions. He channels both the book of Genesis and Plotinus in stating that the notion that a benevolent providence would only create a world which in itself is good goes against the grain of a harder, tragic belief system which perceives of a fallen, wicked earth as a place to plunder and despoil for materials and profit. Although his thinking is not compatible with modern science, Augustine, the most important of early church fathers, arrives at diminished role of humans in the world in ways comparable to that implied by modern science of the seventeenth century, the Enlightenment and Newtonian science of the eighteenth century and the theories of Darwin in the nineteenth century.

The Commentary on the Dream of Scipio (Somnium Scipionis) of Macrobius, who was a Neoplatonist and probably a pagan, was tremendously influential in the Middle Ages. He writes that humankind has, following Stoic doctrine, been frequently all but wiped out by a series of global catastrophes. In his cosmology, the matter that created the universe rises to the ether at the top of the cosmos, while earth, stationary and set at the bottom, is the repository for "the dregs and offscourings of the purified elements" (1.22.5). Macrobius writes: "Insignificant as [the earth] is in comparison with the sky-it is only a point in comparison, though a vast sphere to us" (2.5.10). He echoes many earlier works of literature, including The Dream of Scipio, by stating that only a fraction of the earth is temperate and habitable for humans.

At the beginning of the Middle Ages, Boethius' The Consolation of Philosophy, written in prison in 524, the year of his execution for alleged treachery, became the cornerstone of medieval humanism. Bridging classical traditions with Christianity, the work is about finding happiness and meaning amidst a world of human suffering. Man has a "need to explore and reveal Nature's secret causes"the work makes use of many nature images and metaphors (see Poem 6)--but now the speaker's mind is deadened, and he can only stare at the "dull earth" (1.Poem 2). In a seeming understatement, man is "no small part of [God's] great work," but he is subject to Fortune (1.Poem 5). The anthropocentrism in the work unfolds slowly but is never absolute; the fruits of earth were "given to animals and men," and God wished humans to be above "all earthly things" (2.Prose 5). It is only the human race that stands erect and (evoking contemptus mundi) looks to heaven "despising the earth" (5.Poem 5). Yet when humans forget who they are, they become like beasts (2.Prose 5 and 4.Prose 3). Echoing Cicero's Scipio, human ambition is an empty thing: "the whole circumference of the earth is no more than a pinpoint when contrasted to the space of the heavens." The earth has comparatively "no size at all"; the habitable lands are an "insignificant area on a tiny earth" (2.Prose 7). Through the twelfth century, Boethius, along with Plato's 
Timaeus (by way of Calcidius), Seneca, and Macrobius, would dominate scientific thought (Dales 37).

Granted, none of the ancient writers I have discussed hold what one might call a biocentric or ecocentric viewpoint. Although many thinkers intuitively as well as rationally anticipate such a view, its grounding in science would require evidence beyond the reach of Aristotle, whose physics dominated the west from the thirteenth century until the Renaissance. The astronomical observations of Galileo and the philosophy of Descartes overturned Aristotle. In the nineteenth century, the watershed work of Charles Darwin, and finally the rise of ecological science and environmental ethics in the twentieth century would make biocentrism possible. The tragic effects of the Anthropocene would underscore the importance of challenging anthropocentrism and work their way, eventually, into legislation such as the U.S. Wilderness Act of 1964 and various worldwide attempts (with failures and successes) to control the burning of fossil fuels.

The rise of Christendom would present another story beyond my present scope, but, like the ancients, one labels the early Christian thinkers as purely anthropocentric at much peril. Doubtless, the Bible has been throughout history used much more often to justify the exploitation of the earth than its good stewardship, as espoused by such writers as Wendell Berry and Terry Tempest Williams. ${ }^{15}$ However, portions of it problematize anthropocentrism. As the celebrated translator Robert Alter has written, Job is a "radical rejection of the anthropocentric conception of creation that is expressed in biblical texts from Genesis onward" (The Wisdom Books 3). In Chapter 40, Job briefly, meekly replies (in Hebrew Wisdom parallelism) to Yahweh's heavily poetic speech rife with rhetorical questions: "I am worthless. What can I say back to You? My hand I put over my mouth" (40:3). And in the New Testament, Paul writes that "the earth is the Lord's, and the fullness thereof" (I Cor. 10:26, KJV). Many early church fathers, including Arnobius and John Scotus Eriugena, as well as the great Jewish theologian of the Middle Ages, Moses Maimonides (though an ardent antagonist of Epicureanism), respond negatively to anthropocentrism. ${ }^{16}$ Whatever the case, I have, I think, provided sufficient evidence to challenge the notion-all but a commonplace for some-that the ancients were absolutely anthropocentric in outlook. Far from it.

Submission received 17 August 2015 Revised version accepted 14 March 2016

\footnotetext{
15 In his essay "God and Country," for example, Berry writes, "The ecological teaching of the Bible is simply inescapable: God made the world because He wanted it made. . . . If God loves the world, then how might any person of faith be excused for not loving it or justified in destroying it?" (98). 16 The second chapter of Peterson's Being Human discusses an orthodox Christian position on "human exceptionalism." See also Glacken and pages 55-62 of my own Ecology and Literature.
} 


\section{Works Cited}

Aristotle. Physics. Trans. Robin Waterfield. Oxford: Oxford UP, 2008. Print.

---. On Rhetoric: A Theory of Civic Discourse. 2nd. ed. Trans. George A. Kennedy. New York: Oxford UP, 2006. Print.

---. On the Heavens. W.K.C. Guthrie. Cambridge: Harvard UP, 1939. Print.

Augustine, St. The Confessions. 2nd ed. Trans. Maria Boulding. Hyde Park: New City, 1997. Print.

Becker, Lawrence C. A New Stoicism. Princeton: Princeton UP, 1997. Print.

Berry, Wendell. "God and Country." What are People For? Berkeley: Counterpoint, 1990. 95-102. Print.

Boethius. The Consolation of Philosophy. Trans. Richard Green. Indianapolis: Library of Liberal Arts, 1962. Print.

Cicero. The Nature of the Gods. Trans. P.G. Walsh. Oxford: Oxford UP, 2008. Print.

---. The Republic and The Laws. Trans. Niall Russ. Oxford: Oxford UP, 2009. Crowe, Michael J. Theories of the World from Antiquity to the Copernican Revolution. 2nd ed. New York: Dover, 2001. Print.

Crutzen, Paul J. “Geology of Mankind.” Nature 415 (2002): 23. Print.

Curry, Patrick. Ecological Ethics: An Introduction. 2nd ed. Cambridge, UK: Polity, 2011. 57-60. Print.

Dales, Richard C. The Scientific Achievement of the Middle Ages. Philadelphia: U of Pennsylvania P, 1973. Print.

Danielson, Dennis. The Book of the Cosmos. Cambridge: Perseus, 2002. Print.

Dante. The Inferno of Dante. Trans. Robert Pinsky. New York: Farrar, 1994. Print.

Early Greek Philosophy. Trans. Jonathan Barnes. London: Penguin, 2002. Print.

Gillispie, Charles Coulston. The Edge of Objectivity: An Essay in the History of Scientific Ideas. Princeton: Princeton UP, 1960. Print.

Glacken, Clarence J. Traces on the Rhodian Shore: Nature and Culture in Western Thought from Ancient Times to the End of the Eighteenth Century. Berkeley: U of California P, 1967. Print.

Grayling, A.C. Ideas that Matter: The Concepts That Shape the 21st Century. New York: Basic, 2010. Print.

Greenblatt, Stephen. The Swerve: How the World Became Modern. New York: Norton, 2011. Print.

Hadot, Pierre. What Is Ancient Philosophy? Trans. Michael Chase. Cambridge: Belknap, 2004. Print.

Horace, The Complete Odes and Epodes. Trans. David West. Oxford: Oxford UP, 1997. Print.

Hume, David. Dialogues Concerning Natural Religion. Ed. Martin Bell. London: Penguin, 1990. Print. 
Kahn, Charles. "The Achievement of Early Greek Philosophy: A Drama in Five Acts from Thales to the Timaeus." Early Greek Philosophy: The Presocratics and the Emergence of Reason. Ed. Joe McCoy. Catholic U of America P, 2013. 1-17. Print. Lear, John. Kepler's Dream. Berkeley: U of California P, 1965. Print.

Lindberg, David C. The Beginnings of Western Science: The European Scientific Tradition in Philosophical, Religious, and Institutional Context, Prehistory to A.D. 1450. 2nd ed. Chicago: U of Chicago P, 2008. Print.

Lovelock, James. Gaia: A New Look at Life on Earth. New York: Oxford UP, 1987. Print.

Lucian. Selected Dialogues. Trans. C.D.N. Costa. Oxford: Oxford UP, 2009. Print.

Lucretius. On the Nature of Things: De rerum natura. Trans. Anthony M. Esolen. Baltimore: Johns Hopkins UP, 1995. Print.

Macrobius. Commentary on the Dream of Scipio. Trans. William Harris Stahl. New York: Columbia UP, 1952. Print.

Martial. Epigrams. Trans. Gideon Nisbet. Oxford: Oxford UP, 2015. Print.

Moore, Bryan L. Ecology and Literature: Ecocentric Personification from Antiquity to the Twenty-first Century. New York: Palgrave, 2008. Print.

Oelschlaeger, Max. The Idea of Wilderness: From Prehistory to the Age of Ecology. New Haven: Yale UP, 1993. Print.

Osler, Margaret J. Reconfiguring the World: Nature, God, and Human Understanding from the Middle Ages to Early Modern Europe. Baltimore: Johns Hopkins UP, 2010. Print.

---. "Whose Ends? Teleology in Early Modern Natural Philosophy." Osiris 16 (2001): 151-68. Print.

Peterson, Anna L. Being Human: Ethics, Environment, and Our Place in the World. Berkeley: U of California P, 2001. Print.

Plato. Complete Works. Ed. John M. Cooper. Indianapolis: Hackett, 1997. Print.

Pliny the Elder. Natural History: A Selection. Trans. John F. Healy. London: Penguin, 1991. Print.

Polybius. The Histories of Polybius. Vol. 6. Trans. W. R. Paton. Cambridge: Harvard UP, 1927. Print.

Seneca. Natural Questions. Trans. Harry M. Hine. Chicago: U of Chicago P, 2010. Print.

Theocritus. Idylls. Trans. Anthony Verity. Oxford: Oxford UP, 2002. Print.

The Cynic Philosophers: From Diogenes to Julian. Trans. Robert Dobbin. London: Penguin, 2012. Print.

The Stoics Reader: Selected Writings and Testimonia. Trans. Brad Inwood and L.P. Gerson. Indianapolis: Hackett, 2008. Print.

The Wisdom Books: A Translation with Commentary. Trans. Robert Alter. New York: Norton, 2010. Print.

Virgil. The Georgics. Trans. L.P. Wilkinson. London: Penguin, 1982. Print. 